\title{
Disharmoni Certification in the Authenticity Perspective of the Deed of Establishment of Cooperative by Notaries
}

\author{
Khusnul Yaqin ${ }^{1} \quad$ Endang Prasetyawati ${ }^{2}$ \\ 1.Doctorate of Law Candidate at Law Faculty of 17 Agustus 1945 University of Surabaya, Surabaya, Indonesia. \\ 2.Lecturer of Faculty of Law, 17 Agustus 1945 University of Surabaya, Surabaya, Indonesia
}

\begin{abstract}
Notary is a public official authorized to make authentic deeds and other authorities as referred to in UUJN. Cooperatives as a soko guru economy of the people really need the participation of the government in relation to the establishment, granting the status of legal entities, and amendments to the articles of association and cooperative development are the authority and responsibility of the government. Associated with the deed of ratification of cooperatives as a legal entity in Law No. 25 of 1992 there were no provisions governing cooperative deed-making officials. But in Kepmenkop No. 98 / Kep / M.KUKM / IX / 2004 specifically mentioned in article 4 that Notary makers of cooperative deeds are general officials appointed based on Notary Position Regulations, which are given the authority to, among other things, make deed of establishment, deed of amendment to articles of association and deeds others related to cooperative activities. With the notarial deed of the cooperative which has the authority to make a deed of establishment and amendment to the cooperative statute as stipulated in Kepmenkop No. 98 / Kep / M.KUKM / IX / 2004, then there is a legal conflict with the first legal problem of Disharmoni, the existence of certification of the cooperative establishment deed for notaries as public officials. And the second legal issue is the legal position of Kepmenkop No. 98 / Kep / M.KUKM / IX / 2004 in the perspective of the Act of Notary Position. The completion of the two legal problems uses several legal theories, namely the theory of the purpose of law, the theory of justice, the theory of expediency, the theory of certainty, the theory of authority and the theory of legislation. Besides that, it also uses several concepts, namely the concept of authenticity of deeds, the concept of general officials, professional concepts, the concept of certification, the concept of disharmony and the concept of cooperatives.Kepmenkop No. No. 98 / Kep / M.KUKM / IX / 2004 in the perspective of UUJN, that UUJN in the consideration of the part considering its formation does not refer to Law No. 25 of 1992, but in Kepmenkop No. 98 / Kep / M.KUKM / IX / 2004 section recalls mentioning notary participation. In UUJN no special notary or certified notary was found, and no special deed was found based on ministerial regulations. Therefore Kepmenkop No. 98 / Kep / M.KUKM / IX / 2004 are not based on the provisions stipulated in UUJN that the notary has the authority to make authentic deeds related to the agreement. If the fact is that the cooperative's deed of establishment and / or amendment to the cooperative statute constituting an agreement is made before a notary who has certification as determined by article 4 of Kepmenkop No. 98 / Kep / M.KUKM / IX / 2004, then this is contrary to the tiered theory / theory of legislation, namely stufenbau theory.
\end{abstract}

Keywords: Disharmony of Certification, Authenticity of Notary Deed, Establishment of Cooperatives.

DOI: $10.7176 / \mathrm{JLPG} / 83-03$

Publication date:March $31^{\text {st }} 2019$

\section{Introduction}

The cooperative gets the status of a legal entity after its founding deed was approved by the Government, which in its implementation, the government can delegate that authority to the Minister in charge of cooperatives, however this does not mean that the government interferes in the internal affairs of the Cooperative organization and still considers the Cooperative's independence principle This means that the ratification of cooperatives as a legal entity by the government does not affect the independence of cooperatives as a legal entity formed aimed at promoting the welfare of members in particular and society in general.

Ratification of cooperatives as legal entities after the establishment deed was approved by the government in this case the Minister of Cooperatives. Sociologically, legal pluralism is still recognized and implemented in social life. There are people who implement state law, there are also customary law communities and religious law. The three legal systems, live side by side with one another (co-existens). The legal system lives side by side with one another, it is hoped that there will be a law of hormonalization. Harmonization in law includes adjusting legislation, government decisions, judges' decisions, legal systems and legal principles with the aim of increasing legal unity, legal certainty, justice and comparability, usability and legal clarity, without obscuring and sacrificing legal pluralism "1

The harmonization of the law guarantees legal certainty, other than if there is no harmonization of the legal

\footnotetext{
${ }^{1}$ Kusnu Goesniadhie, Harmonisasi Hukum Dalam Persfektif perundang-undangan; Lex Specialis Suatu Masalah, (Surabaya; JP Books,
} 2006), h. 100. 
system, a situation will arise that cannot guarantee legal certainty that can cause disruption in community life, disorder and a sense of unprotectedness. "In this perspective the problem of legal certainty will be felt as a need that can only be realized through harmonization of the legal system"1(2) legal disharmony is related to the authority of the notary to make authentic deeds based on UUJN, which means that the authority of the notary as a public official makes an authentic deed, except for an authentic deed made by a special official. In fact, making authentic deeds related to cooperatives, the Minister of Cooperatives issued Kepmenkop No. 98 / Kep / M.KUKM / IX / 2004, which appoints a special notary (certified) in making a cooperative establishment deed

\section{Formulation of the Problems}

Based on the description above, the problem is:

1. Disharmoni is the existence of certification of cooperative establishment deeds for notaries as public officials

2. Legal status of Kepmenkop No. 98 / Kep / M.KUKM / IX / 2004 in the perspective of the Act on Notary Position (hereinafter referred to as UUJN).

\section{Research Methods}

The research method is a way or path or process of examination or investigation that uses a method of reasoning or thinking that is "logical-analytical (logic), based on the arguments, formulas and theories of a particular science (or several branches of science), to test truth (or verification) a hypothetical or theory about symptoms or scientific events, social events or certain legal events "2

"The research method used in this study is a normative legal research method. The choice of this method, as written by Peter Mahmud Marzuki, ${ }^{3}$ that legal research is the process of finding legal rules, legal principles, and legal doctrines in order to answer the legal issues at hand. Furthermore Peter Mahmud Marzuki stated that legal research is a scientific process to find solutions to legal issues that arise with the aim of giving a presception about what should be the legal issues that arise. So the legal research method that we use is a normative legal research method

\section{Analysis and Results}

\section{Disharmoni Existence of Certification of The Notary of The Cooperation As a General Officer}

Cooperatives as one of the economic actors in Indonesia in addition to state-owned and private enterprises. As economic actors, cooperatives are expected to contribute significantly to national development. In fact the role of cooperatives is still far from what is expected. But this fact should not be an obstacle to getting to know more about cooperatives. Especially for observers or those who want to be more involved in cooperatives, it is necessary to look at the characteristics that distinguish them from two other economic actors, will be an effective learning of the importance of living in collaboration, especially through cooperatives

Building a true cooperative means being committed to being a pioneer of the cooperative movement that is able to step on sharp gravel and take on a number of challenges in realizing a vision of making Indonesia a developed country, this is a struggle as a nation to be able to answer the challenges of globalization in the real sense. Why not, when the issue of rolling out 'ordinary' cooperatives alone has many obstacles both from internal (founders and members) and from external (instant climate of cooperatives in Indonesia), especially when a dream emerges to realize a true cooperative.

In the following developments Law No. was issued. 25 of 1992. "Cooperatives formed with a philosophical foundation are considerations or reasons that illustrate that the regulations formed take into account the views of life, awareness and ideals of the law which include the atmosphere of mysticism and the philosophy of the Indonesian people originating from the Pancasila"4 The philosophical foundation for drafting Law No. 25 of 1992 stated in legal considerations in letter a, which determines:

Cooperatives, both as a people's economic movement and as a business entity play a role in realizing an advanced, just and prosperous society based on Pancasila and the 1945 Constitution in the national economic order which is structured as a joint effort based on the principle of family and economic democracy ".

Cooperatives as joint business activities among its members, including types of businesses incorporated as legal entities, so that as legal entities can act in law. The legal body of the deed of establishment was made in the form of an authentic deed, namely an akra made before a notary. However, there is not a single article stating that the deed of establishment of a cooperative as a legal entity is made in the form of an authentic deed made before a notary. This shows that the existence of a collaboration of members to carry out cooperative activities

\footnotetext{
${ }^{1}$ Ibid.,h.107.

2 C.F.G. Sunaryati Hartono, Penelitian Hukum Di Indonesia Pada Akhir Abad Ke 20. Alumni Bandung, 1994, h. 105.

${ }^{3}$ Peter Mahmud Marzuki, Penelitian Hukum, Jakarta: Kencana, 2007, h. .35.

${ }^{4}$ Salim HS dan Erlies Septiana Nurbani, Penerapan Teori Hukum pada Penelitian Tesis dan Disertasi, RajaGrafindo Persada, Jakarta, 2013, h. 38
} 
does not emphasize the existence of a deed made before a notary as a general official who makes the deed of establishment of a limited liability company or foundation that is both a legal entity and a cooperative

The need to understand the basis of the issuance of Kepmenkop No. 98 / Kep / M.KUKM / IX / 2004 is to find out the background of the appointment of a certification notary by the Minister of Cooperatives to make a deed of establishment and or deed of amendment to the articles of association of the notary. First understanding of the publication of Kepmenkop No. 98 / Kep / M.KUKM / IX / 2004 is related to the legal principle is an important element of a legal regulation, it can even be said as the 'heart' of legal regulations.

The existence of Kepmenkop No. 98 / Kep / M.KUKM / IX / 2004 reviewed from the systematics of legislation, as stipulated in article 7 paragraph (1) of Law No. 12 of 2011 concerning the Establishment of Laws and Regulations, stated that the type and hierarchy of Laws and Regulations consist of the 1945 Constitution of the Republic of Indonesia, Provisions of the People's Consultative Assembly, Government Acts / Regulations Substituting Laws, Government Regulations, Presidential Regulations, Provincial Regulations, and Regency / City Regulations, Kepmenkop No. 98 / Kep / M.KUKM / IX / 2004 is not one of the laws and regulations, so it does not have binding power to be implemented.

The promulgation of Kepmenkop No. 98 / Kep / M.KUKM / IX / 2004 in order to improve the quality of legal services, meaning to improve the quality of acts of service according to the law or rules that apply in the field of cooperatives is everything that concerns the life of the Cooperative, especially those relating to processes, procedures and procedures establishment, amendment to articles of association and other deeds related to cooperative activities, efforts are needed to ensure legal certainty regarding the deeds of cooperatives through the use of authentic deeds. Guaranteeing legal certainty, is a protection of the judiciary against arbitrary actions, which means that someone will be able to obtain something expected in certain circumstances. The community hopes for legal certainty, because with the legal certainty the community will be more orderly. Law is in charge of creating legal certainty because it aims at public order. ${ }^{1}$

Associated with cooperatives, legal certainty is expected to provide legal protection regarding the life of the Cooperative, especially relating to the processes, procedures and procedures for establishment, amendments to the articles of association and other deeds. The deed referred to is the deed of establishment, procedures and procedures for establishment, amendment to the articles of association through the use of authentic deeds, namely an authentic deed is a deed made in a statutory form by or before the authorized official for that at the place of the deed made as Article 1868 of the Civil Code.

An authentic deed is a deed made in the presence of a public official who is authorized for it at the place where the deed was made, the general official referred to as the consideration of the Considering Section of Kepmenkop No. 98 / Kep / M.KUKM / IX / 2004, that with regard to the objectives as intended, it is necessary to mobilize the participation of notaries in making deeds in the process of ratifying the deed of establishment and amendment to the articles of association of the cooperative. This means that what is meant by a public official is a notary.

The deed of establishment of cooperatives is an agreement made by the founders of the cooperative. The agreement referred to as Cooperative Law and Kepmenkop No. 98 / Kep / M.KUKM / IX / 2004 does not provide definitions and further regulate the agreement, so that the agreement used as stipulated in Book III of the Civil Code concerning Engagement.

An agreement is an act in which one or more people bind themselves to one or more other people as stated in Article 1313 of the Civil Code. Subekti interpreting an agreement is an event in which a person promises to another person or where two people promise each other to do something. ${ }^{2}$

Two or more people tie themselves together to do something. The parties that agree are the founders of the cooperative, but Law No. 25 of 1992 does not provide a definition of the founders of cooperatives. The founder according to the Big Dictionary of Indonesian Language is the people who first founded the association, the company, the founder of the cooperative meant the people who first founded the cooperative

Disharmony between notaries as public officials and notaries as public officials is binding when different grammatical interpretations are used which generally occur in written language. ${ }^{3}$ Grammatical interpretation is interpreting the law according to the meaning of the word (term). Between language and law there is a very close relationship. Language is the only tool that lawmakers use to express their will, but sometimes lawmakers cannot arrange the right words. ${ }^{4}$

The special official referred to is not a notary, so if the special official who makes the cooperative deed is a notary who has an evidence certificate that has attended debriefing in the field of Cooperatives signed by the Minister as stated in article 4 letter b Kepmenkop Number 98 / KEP / M.KUKM / IX / 2004.

Certified notary and notary notary have attended debriefing in the field of Cooperatives signed by the

\footnotetext{
${ }^{1}$ Sudikno Mertoskusumo, Mengenal Hukum (SuatuPengantar), Liberty, Yogyakarta, 1988, h. 58

${ }^{2}$ Subekti, Op. Cit., h. 1

${ }^{3}$ Abdul Chaer, Psikolinguistik: Kajian Teoretik, Rineka Cipta, Jakarta, 2003, h. 307.

${ }^{4}$ Yudha Bhakti Ardiwisastra, Penafsiran dan Konstruksi Hukum, Alumni, Bandung, 2012, h. .9
} 
Minister, giving rise to a doubt or not at all understood by others, this occurs because in terms of vertical notary rules as general officials are based on UUJN, while notary makers cooperative deed based on Law No. 25 of 1992. In terms of the horizontal notary as a public official is a legal product of the Minister of Law and Human Rights, while a certified notary is a product of the Minister of Cooperatives. The issuance of Kepmenkop Number 98 / KEP / M.KUKM / IX / 2004 on the Consideration of the Section Considering the existence of the certification notary does not refer to UUJN (Notary Position Regulations).

The existence of a certified notary has made UUJN as a statutory regulation by the Minister of Cooperatives associated with the theory of the usefulness of the law as a useless regulation, even though according to the law of benefit the rule is the most important thing in a legal goal. The purpose of law can be seen in its function as a function of protecting human interests, the law has goals to be achieved. ${ }^{1}$ If we look at the definition of benefits in a large Indonesian dictionary, the benefits in terms of terminology can be interpreted as useful or useful. ${ }^{2}$ Benefits according to Black Law A particular and peculiar benefit or advantage enjoyed by a person, company, or class, beyond the common advantages of other citizens. An exceptional or extraordinary power or exemption. A right, power, franchise, or immunity held by a person or class, against or beyond the course of the law.

This means that in the practice of making authentic deeds, especially the cooperative deed as a legal entity as other legal entities, namely Limited Liability Companies and Foundations, it was found that the cooperative establishment deed was made by a certification notary appointed by the Minister of Cooperatives and the deed of establishment was approved by the Minister of Cooperatives. Certified notary is a notary as a public official regulated in UUJN, so that it does not cause harmony and UUJN as the only legislation that regulates a notary public as a re-enforced official, especially related to notary certification, as a notary in general

\section{Kepmenkop Legal Position NO. 98 / KEP / M.KUKM / IX / 2004 in The Perspective of Law Number 2 OF 2014 Concerning Amendment to Law Number 30 of 2004 Concerning Notary Position}

Kepmenkop No. 98 / KEP / M.KUKM / IX / 2004, in essence that the deed of establishment and cooperative change must be made in an otenktik deed related to an agreement made before a notary has a certificate of proof having participated in debriefing in the field of Cooperatives signed by the Minister. It is necessary to know the strength of law as evidence of the deed of establishment and amendment to the cooperative articles of association made before a certification notary, which is unknown in the UUJN. The legal strength of the cooperative deed made by a certified notary is viewed in terms of the theory of legal certainty, the theory of authority, the usefulness theory and the systematic theory of legislation, to determine the authority of certification requirements and the legal consequences of deeds related to cooperatives made by notary certification

Deed as written evidence can be made in the form of a deed under the hand and can also be made in the form of an authentic deed. Written evidence is also called a letter, is everything that contains reading signs intended to pour out the contents of the heart or to convey ideas and be used as proof. ${ }^{3}$ Written evidence or letter is used as proof, but not all written documents or proof have the evidentiary power of a legal act, therefore the letter is distinguished between ordinary letters, authentic deeds, and underhanded deeds. ${ }^{4}$

The notary maker of cooperative deeds is found in Kepmenkop Number 98 / KEP / M.KUKM / IX / 2004, explicitly mentioning that notary makers of cooperative certificates are notaries as public officials authorized to carry out positions in accordance with UUJN and have proof certificates following the briefing in the field of Cooperatives. The presence of a notary as a public official is regulated in UUJN and a certification notary as Kepmenkop Number 98 / KEP / M.KUKM / IX / 2004 shows a disharmony or disharmony or disharmony, even though every scientific activity is expected to lead to a written harmonization process which refers to both philosophical, sociological, economic and juridical values.

The philosophical foundation is a consideration or reason that illustrates that the regulations formed take into account the views of life, consciousness, and legal ideals which include the atmosphere of mysticism and the philosophy of the Indonesian nation originating from Pancasila and the Preamble of the 1945 Constitution. The philosophical foundation is the Law of the Republic of Indonesia. guarantee certainty, order and legal protection for every citizen; that in order to ensure certainty, order and legal protection, authentic written evidence is needed regarding acts, agreements, stipulations, and legal events made before or by authorized officials. Notary as a public official who runs a profession in providing legal services to the public, needs to get protection and guarantees in order to achieve legal certainty. The foundation was issued by Kepmenkop Number 98 / KEP / M.KUKM / IX / 2004 that in the framework of improving the quality of legal services in the field of cooperatives, especially those relating to processes, procedures and procedures for establishment, amendments to the articles of association and other deeds related to activities cooperatives, efforts are needed to ensure legal certainty regarding the deeds of cooperatives through the use of authentic deeds. In connection with the intended

\footnotetext{
${ }^{1}$ Said Sampara dkk, Pengantar Ilmu Hukum, Total Media, Yogyakarta, 2011, h. 40.

${ }^{2} \mathrm{KBBI}$, http://kbbi.web.id/manfaat, diakses Tanggal 23-06-2015 291

${ }^{3}$ Sudikno Mertokusumo, Hukum Acara Perdata Indonesia, Liberty, Yogyakarta, 2002, h. 141-142

${ }^{4}$ Nur Rasaid, Hukum Acara Perdata, Sinar Grafika, Jakarta, 1996, h. 38
} 
purpose, it is necessary to mobilize the participation of notaries in making deeds in the process of ratifying the founding deed and amending the articles of association of the cooperative.

The foundation of UUJN and Kepmenkop Number 98 / KEP / M.KUKM / IX / 2004 there is a similarity that in making deeds (establishment, changes and other deeds regarding cooperatives) there is a need for a notary as a public official and a notary ready to participate in notary drafting on the process of ratification of the deed of establishment and amendment to the cooperative statutes, so that in the preparation of deed of incorporation, amendments and other deeds concerning cooperatives, the Minister of Cooperatives appoints a notary certificate as a disharmony between the public notary and certified notary issued by the Minister of Cooperatives.

Notaries as public officials and notaries as certified public officials are each regulated in UUJN and Law No. 25 of 1992, PP Bi. 9 of 1999 and Kepmenkop No. 98 / KEP / M.KUKM / IX / 2004, as a number of laws and regulations simultaneously in the same time and space namely notary public has the authority to make authentic deeds, certainly has consequences the occurrence of legal disharmony. The legislation makes overlapping authority and conflict of interest, the application of various types of legislation together without efforts to harmonize the law or harmonize and harmonize will certainly lead to conflicts of interest between institutions. Each legislation has goals, strategies to achieve goals, and guidelines for implementing the strategy, where all three of these are often formulated in the form of policies.

The potential for legal disharmony according to Kusnu Goesniadhie is reflected in the existence of factors including the excessive number of laws and regulations that are enacted, including UUJN explicitly authorizing the making of authentic deeds, Law No. 25 of 1992 and PP No. 9 of 1995 only mentions the deed of establishment and deed of amendment to the articles of association (authentic deed and underhanded deed), Kepmenkop Number 98 / KEP / M.KUKM / IX / 2004 only mentions the deed of establishment and deed of amendment to the articles of association made by a notary certification. There are differences in interests and interpretations between the notary appointed and dismissed by the Minister of Law and Human Rights, while the certification notary is appointed and dismissed by the Minister of Cooperatives, each of whom has an interpretation related to the notary as a public official and notary certification.

Harmonization of law is an effort or process of adjusting the principle and legal system. Associated with the formation of laws and regulations, harmonization of law as a process of overcoming conflicting matters and irregularities between legal norms in the laws and regulations, so as to form harmonious national legislation, in the sense of harmony, harmony, balanced, integrated and consistent, and obedient to the principles and the realization of legal simplicity, legal certainty and justice

Notary as a public official in the Notary Code of Ethics article 3 point 16 stated that the notary is obliged to create a family atmosphere and togetherness in carrying out office tasks and daily activities and treat each other colleagues well, respect each other, respect each other, help each other and always try to establish communication and friendship. The existence of a shared fellow notary treats each other colleagues well, mutual respect, mutual respect, help each other and always try to establish communication and friendship, indicating that only one notary is incorporated in an organization (eg the Indonesian Notary Association).

The presence of the notary public to realize public justice / notary public officials must be returned to the original structure. This task is the duty of the state to stop change, so justice is not about relations between individuals but individual and state relations.

Justice is also understood metaphysically as being the quality or function of super human beings, whose properties cannot be observed by humans. The consequence is that the realization of justice is shifted to another world, beyond human experience; and human reasoning which is essential for justice is subject to God's irreversible ways or unexpected decisions of God. ${ }^{1}$ On the requirement to become a notary if the notary is required to fear the Almighty God, the state must create justice as God creates the same human and equal treatment.

Justice according to John Rawls's concept affirms his view of justice that a democratic dimension of justice enforcement program must pay attention to the two principles of justice, namely, first, giving equal rights and opportunities to the broadest basic freedom for everyone in this case is a notary in making authentic deeds without distinguishing between notary and notary certification. Second, being able to rearrange the socioeconomic disparities that occur so that they can provide reciprocal benefits. ${ }^{2}$ The Minister of Cooperatives, which only provides legality in the establishment of deed of establishment, deed of change and other deeds related to cooperatives to notary certification, has created an injustice that is not fair among notaries.

Justice in a special sense is related to the following meanings, namely:

a. Something that is manifested in the distribution of awards or money or other things to those who have part of their rights.

\footnotetext{
${ }^{1}$ W. Friedmann, Teori dan Filsafat Hukum, (Legal Theori), Susunan I, diterjemahkan oleh Mohamad Arifin, Cetakan kedua, Jakarta (PT RajaGrafindo Persada, 1993), h. 117.

${ }^{2}$ Rawls, John, Teori Keadilan Dasar-Dasar Filssafat Politik Untuk Mewujudkan Kesejahteraan Sosial Dalan Negara, Pustaka Pelajar, Yogyakarta, 2011
} 
This justice is the equality between community members in an act together. Equation is a point located between "more" and "less" (intermediate). So justice is the midpoint or a relative equation (arithmetical justice). The basis of equality between community members is very dependent on the system that lives in the community. In a democratic system, the common ground for obtaining the midpoint is human freedom which is equal since its birth. In the oligarchy system the basic equation is the level of welfare or honor at birth. Whereas in the aristocracy system the basic similarity is privilege (excellent). These different bases make justice more than the meaning of equations as proportions. This is a special species of justice, namely intermediate and proportion. The notary in carrying out the position makes an authentic deed obtaining an honorarium whose amount has been limited by the provisions of Article $36 \mathrm{UUJN}$, so that the certified notary is not permitted to receive the honorarium beyond the provisions of Article 36 UUJN when making deed of incorporation, deed of amendment to the Articles of Association and other deeds when making the deed.

b. Repairing a part of the transaction

Another special meaning of justice is rectification. Improvements arise because of the voluntary relationship between people and people. The relationship is a justice if each gets a part to the intermediate point, or an equation based on the principle of reciprocity. So justice is equality, and injustice is inequality. Injustice occurs when one person gets more than the other in an equal relationship. Justice in this case is the middle point between unfair actions and being treated unfairly.(16) The honorarium limit has been determined by law, and if violating the UUJN will be subject to UUJN sanctions, besides that it will be subject to ethical sanctions on the basis of violating the Notary Code of Ethics.

Based on the description as mentioned above, it can be explained that there is a disharmony between certified notaries and notaries, which are collapsed between notaries and notaries certified in exercising their authority. If a notary as a public official has the authority to make an authentic deed other than the cooperative establishment deed, the deed of amendment to the articles of association and other deeds related to the cooperative, this is different from the notary certification, because in addition the notary has the authority to make authentic deeds as well, is also authorized to make deeds establishment of cooperatives, deed of amendment to cooperative articles of association and other deeds related to cooperatives

Legal disharmony occurs, legal harmony and harmony are needed to create good governance, and legal disharmony that has not yet occurred must be prevented through efforts to harmonize, harmonize and adjust various harmonization activities of the law. Likewise, inconsistencies in imposing sanctions on violations of law lead to legal disharmony that must be harmonized through harmonization and harmonization of laws governing notaries as public officials so as not to cause a thing that overlaps the notary in carrying out his position.

\section{Conclusion}

1. The issuance of Kepmenkop No. 98 / Kep / M.KUKM / IX / 2004 does not bring benefits and makes the notary overlap in making the deed, where NPAK is appointed and dismissed by the Minister of Cooperatives in collision with a Notary who should be appointed and dismissed by Menkumham.

2. In the UUJN counseling the recall section does not refer to Law number 25 of 1992 concerning Cooperatives, but in Kepmenkop No. 98 / Kep / M.KUKM / IX / 2004 the weighing section needs to raise the participation of Notaries, where the notary refers to the UUJN. Whereas in UUJN no special notary / certification was found or not found for certain deeds must be with certain regulations.

\section{Suggestion}

1. Certification does not have legal force and can even be null and void due to disharmony, so it must return the authority to make cooperative deeds to the notary as a public official. Harmonized with the way the executive and the legislature make changes to the cooperative law.

2. Position of Kepmenkop No. 98 / Kep / M.KUKM / IX / 2004 does not have legal force to be implemented, it needs to be revoked / canceled because of a norm conflict.

\section{Refference}

Ardiwisastra, Yudha Bhakti, Penafsiran dan Konstruksi Hukum, Alumni, Bandung, 2012

Chaer, Abdul, Psikolinguistik: Kajian Teoretik, Rineka Cipta, Jakarta, 2003

Darmodiharjo, Darji, dan Shidarta Pokok-pokok Filsafat Hukum (Apa dan Bagaimana Filsafat Hukum Indonesia), Gramedia Pustaka Utama, Jakarta, Cet, VI Mei 2006

Friedmann, W., Teori dan Filsafat Hukum, (Legal Theori), Susunan I, diterjemahkan oleh Mohamad Arifin, Cetakan kedua, Jakarta, RajaGrafindo Persada, 1993

Goesniadhie, Kusnu, Harmonisasi Hukum Dalam Persfektif perundang-undangan; Lex Specialis Suatu Masalah, (Surabaya; JP Books, 2006.

Hartono, C.F.G. Sunaryati, Penelitian Hukum Di Indonesia Pada Akhir Abad Ke 20. Alumni Bandung, 1994

KBBI, http://kbbi.web.id/manfaat, 
Marzuki, Peter Mahmud, Penelitian Hukum, Jakarta: Kencana, 2007

Mertokusumo, Sudikno, Hukum Acara Perdata Indonesia, Liberty, Yogyakarta, 2002 , Mengenal Hukum (SuatuPengantar), Liberty, Yogyakarta, 1988

Rasaid, Nur, Hukum Acara Perdata, Sinar Grafika, Jakarta, 1996

Rawls, John, Teori Keadilan Dasar-Dasar Filssafat Politik Untuk Mewujudkan Kesejahteraan Sosial Dalan Negara, Pustaka Pelajar, Yogyakarta, 2011

Salim dan Erlies Septiana Nurbani, Penerapan Teori Hukum pada Penelitian Tesis dan Disertasi, RajaGrafindo Persada, Jakarta, 2013

Subekti, Hukum Perjanjian, Intermasa, Jakarta, 2004

Sampara, Said dkk, Pengantar Ilmu Hukum, Total Media, Yogyakarta, 2011 